\title{
Whey Proteini İzolatının Rat Böbreğine Histolojik Etkileri
}

\author{
Histological Effects of Whey Protein Isolate on Rat Kidney
}

\author{
Özden Kutlay' ${ }^{1}$ Esra Aslan ${ }^{2}$
}

Geliş tarihi/Received: 01.05.2020 • Kabul tarihi/Accepted: 21.07.2020

\section{ÖZET}

Amaç: Whey proteini diğer yapısal proteinlere göre daha fazla miktarda dallı zincirli aminoasit içeren tam bir proteindir. Bu proteinin uzun süreli kullanımının böbrek dokusunda meydana getirdiği histolojik değişiklikler henüz araştırılmamıştır. Bu çalışmada düzenli olarak bir ay boyunca gavaj ile whey protein izolatı verilen ratların böbrek dokusundaki histolojik parametrelerin değerlendirilmesi amaçlanmıştır.

Gereç ve Yöntem: Bu çalışma Afyonkarahisar Sağlık Bilimleri Üniversitesi Tıp Fakültesi Fizyoloji Anabilim Dalı ve Histoloji ve Embriyoloji Anabilim Dalı’nda, 250-300 g ağırlığında 30 adet Wistar Albino erkek sıçan kullanılarak yapılmıştır. Her grupta 10'ar sıçan olacak şekilde kontrol, sham ve whey proteini uygulanan grup olarak 3 gruba ayrılmıştır. Kontrol grubuna herhangi bir uygulama yapılmazken, sham grubuna $1 \mathrm{~mL}$ çeşme suyu, whey proteini grubuna $6 \mathrm{~g} / \mathrm{kg} / \mathrm{gün}$ whey proteini $1 \mathrm{~mL}$ çeşme suyunda çözünerek bir ay boyunca gavajla verilmiştir. Böbrek dokusundaki genel morfolojik değişiklikleri incelemek için Hematoksilen-Eozin, PAS ve Masson-Trikrom boyamaları yapılmıştır. Böbreklerdeki IL-6, FGF-1, p53 ekspresyonlarını değerlendirmek için dokular immunohistokimyasal olarak boyanmıştır.

Bulgular: Whey protein grubunda hafif mezengial matriks genişlemeleri görülmekle beraber hem bu grupta hem de diğer gruplarda bunun dışında başka bir patolojiye rastlanmamıştır. Whey protein grubunda IL-6 ve FGF-1 boyanmaları diğer gruplara göre istatistiksel olarak anlamlı bir artış göstermiştir $(\mathrm{p}<0.05)$.

Sonuç: Whey proteini verilen sıçanların böbreklerinde histolojik ve morfolojik bir değişiklik görülmemiştir. Bununla beraber IL-6 ve FGF-1 ekspresyonlarının artmış düzeylerinin, fizyopatolojik deneysel hayvan modellemelerinde yol gösterici olması açısından önemlidir.

Anahtar kelimeler: Whey protein, IL-6, FGF-1, böbrek dokusu

\section{ABSTRACT}

Aim: Whey protein is a complete protein that contains more amount of branched chain amino acids than other structural proteins. Histological changes in long-term use of this protein in kidney tissue have not been studied yet. In this study, it was aimed to evaluate the histological parameters in the kidney tissue of rats given whey protein isolate regularly for a month.

Material and Method: This study was carried out using 30 Wistar Albino male rats weighing 250-300 g in Afyonkarahisar Health Sciences University Faculty of Medicine, Physiology Department and Histology and Embryology Department. Control, sham and whey protein groups were divided into 3 groups with 10 rats in each group. While no application was made to the control group, $1 \mathrm{~mL}$ of tap water was given to sham group and $6 \mathrm{~g} / \mathrm{kg} /$ day of whey protein was dissolved in $1 \mathrm{~mL}$ of tap water

1. İletişim/Correspondence: Afyonkarahisar Sağllk Bilimleri Üniversitesi, Tıp Fakültesi, Fizyoloji Anabilim Dall, Afyonkarahisar, Türkiye

E-posta: ozden.2007@gmail.com • ๑ https://orcid.org/0000-0001-5509-6650
2. Afyonkarahisar Sağlık Bilimleri Üniversitesi, Tıp Fakültesi, Histoloji ve Embriyoloji Anabilim Dalı, Afyonkarahisar, Türkiye • ๑ https://orcid.org/0000-0002-3191-4978 
then given to whey protein group for 1 month. Hematoxylin-Eosin, PAS and Masson-Trichrome staining were performed to examine general morphological changes in kidney tissue. Tissues were immunohistochemically stained to evaluate IL-6, FGF-1, p53 expressions in kidneys.

Results: Although mild mesengial matrix dilatations were seen in the whey protein group, no other pathology was observed in this group and other groups. IL-6 and FGF-1 dyes in the whey protein group showed a statistically significant increase compared to other groups $(\mathrm{p}<0.05)$.

Conclusion: Histological and morphological changes were not observed in the kidneys of the rats given whey protein. However, increased levels of IL-6 and FGF-1 expressions are important in terms of being a guide in the physiopathological experimental animal modelings.

Keywords: Whey protein, IL-6, FGF-1, kidney tissue

\section{GİRIŞ}

Peynir altı suyu (whey proteini) sekiz esansiyel amino asit içeren tam bir proteindir. Whey proteini diğer yapısal proteinlerle kıyaslandığında dallı zincirli aminoasitleri daha fazla miktarda içermektedir. Piyasada hızlı emilim özelliğinden dolayı en yaygın kullanılan formu izole hidrolize whey proteinidir (1). Whey proteinlerindeki bu aminoasitlerin hidrolizasyonu daha kolaydır ve protein alımından sonra dakikalar içerisinde plazma seviyeleri yükselir (2). Bu nedenle whey proteini de diğer supplementler, örneğin protein tozu ve amino asit kapsülleri gibi, sporcular tarafindan vücut kompozisyonunu geliştirmek ve performansı artırmak için kullanılır (3). Whey proteini, lösin, izolösin ve valin gibi dallı zincirli amino asitleri yüksek miktarda içermesi nedeniyle anabolik bir etki oluşturarak (4), kas büyümesi, onarımı ve yapımında olumlu etkiler gösterir (5).

Daha önce yapılmış bir çalışma, whey proteinin postprandial glikozu azaltabileceğini göstermektedir (6). Antioksidan ve anti-inflamatuvar özelliklere sahip olan whey proteini, insülin ve glukagon sekresyonunu uyarır. Böylece beklendiği gibi kan glukoz düzeyini düşürür ve mide boşalmasını geciktirir $(5,7)$. Whey proteininin, lenfosit stimülasyonu ile fagositozu ve peyer plaklarında immünglobulin A sekresyonunu artırarak, immün düzenleyici özelliklerinin olduğu rapor edilmiştir. Bu etkilerini, esas olarak içeriğindeki laktoferrin nedeniyle gerçekleştirdiği saptanmış olan whey proteininin immünglobülinler, laktoperoksidaz gibi proteinlerle de immün düzenleyici veya anti inflamatuvar etkilerinin olduğu gösterilmiştir (8). Ayrıca $\beta$-laktoglobulin ve a-laktalbumin gibi whey proteinlerinin makrofajlardan interlökin-1 (IL1) üretimini arttırdıkları saptanmıştır (9). Whey proteinlerinin antioksidan ve detoksifiye edici etkisi glutatyon sentezine yaptığı katkı üzerinden gerçekleşmektedir. Antioksidan tiyol grubu içeren sisteinin, glisin ve glutamat birleşmesi sonucu glutatyon oluşmaktadır. Glutatyon ve okside formu glutatyondisülfit (GSSH) arasındaki redoks siklusu sayesinde ribonükleik asit (RNA), deoksiribonükleik asit (DNA) ve proteinlerin üretimini destekleyen glutatyon, esas endojen antioksidandır (10).

Whey proteinlerinin vücut sistemleri üzerine olan olumsuz etkisi ile ilgili çalışmaların, özellikle de deneysel çalışmaların son derece yetersiz olduğu görülmektedir. Nunes et. al'un (11) çalışmasında, 32 gün gavaj ile verilen whey proteininin sedanter farelerde karaciğer ve böbrek hasarı ile ilişkili belirteçleri arttırdığı, egzersiz grubunda ise fizyolojik kardiyak hipertrofiye neden olduğu saptanmıştır. Whey proteinin uzun süre kullanılmasında, böbrek dokusu üzerinde oluşturabileceği olası histolojik ve morfolojik değişiklikler ise henüz araştırılmamış bir konudur. Bu çalışmada, bir ay boyunca düzenli olarak gavaj ile whey protein izolatı verilmiş olan ratların böbrek dokusundaki histolojik parametrelerin değerlendirilmesi amaçlanmıştır. $\mathrm{Bu}$ bağlamda, 
inflamatuvar belirteçlerden birisi olan IL-6 böbrek hasarında önemli bir değişken olabilecek bir büyüme faktörü olan Fibroblast Büyüme Faktörü-1 (FGF1), proapoptotik veya antiapoptotik yol izlerinin kontrolünde önemli bir rolü olan protein 53 (p53) protein üçlüsü ve whey proteini verilecek olan ratların böbrek dokusunda oluşturacağı olası değişiklikler arasında ilişki kurulabileceği ön görülmüştür. Elde edilen sonuçların, gelecekteki whey proteini ile ilişkilendirilebilecek renal çalışmaların kurgulanmasında alt yapının oluşturulabileceği ve insanlar üzerinde yapılması planlanan klinik çalışmalara öncü olabileceği düşünülmektedir.

\section{GEREÇ VE YÖNTEM}

$\mathrm{Bu}$ çalışma Afyon Kocatepe Üniversitesi Deney Hayvanları Uygulama ve Araştırma Merkezi Hayvan Deneyleri Yerel Etik Kurulundan onay alındıktan sonra başlatılmıştır (Onay numarası: (2019/137-19). Deneysel çalışmalar Afyonkarahisar Sağlık Bilimleri Üniversitesi Tıp Fakültesi Fizyoloji Anabilim Dalı ve Histoloji ve Embriyoloji Anabilim Dalı'nda ortak şekilde yürütülmüştür. Çalışmada ağırlıkları 250$300 \mathrm{~g}$ arasında değişen toplam 30 adet Wistar Albino erkek sıçan kullanılmıştır. Bu araştırmada örneklem büyüklüğü hesabı 0.05 anlamlılık düzeyi, $\mathrm{f}=0.60$ etki büyüklüğü ve 0.80 güç ile one-way ANOVA kullanılarak yapılmış ve 30 sıçandan oluşan örneklemin yeterli olacağı saptanmıştır. Sıçanlar Afyon Kocatepe Üniversitesi Veterinerlik Fakültesi Deney Hayvanları Uygulama ve Araştırma Merkezinde barındırılmıştır. Standart ticari yemle ve standart çeşme suyu ile beslenmiş olan sıçanlar $22 \pm 2$ 0C sıcaklıkta, 12 saat karanlık ve 12 saat aydınlık döngüsüne maruz bırakılmıştır. Bu süre içerisinde günlük tüketeceği su ve yem miktarı tüm gruplarda eşit tutulmuştur. Bir hafta adaptasyon süresi beklendikten sonra deneye başlanmıştır. Sıçanlar kontrol grubu (Grup 1), sham grubu (Grup 2) ve whey proteini uygulanan grup (Grup 3) olmak üzere toplam üç gruba ayrılmıştır. Whey proteini grubunda, whey proteini $6 \mathrm{~g} / \mathrm{kg} /$ gün dozunda, $1 \mathrm{~mL}$ çeşme suyunda çözüldükten sonra bir ay süreyle her gün oral gavaj ile sıçanlara verilmiştir. Sham grubuna da aynı yöntemle sadece 1 mL çeşme suyu verilirken kontrol grubunda herhangi bir uygulama yapılmamıştır. Oral gavaj uygulaması bir ayın sonunda tamamlandığında sıçanlar uygun anestezi altında feda edilmiştir.

Çalışma protokolünün sonunda otopsileri yapılan sıçanların böbrek dokuları dikkatli bir şekilde kesilip alındıktan sonra serum fizyolojik ile temizlenmiştir. Daha sonra, \%10’luk formalin bulunan renkli şişelere aktarılmıştır. Alınan böbrek dokuları \%10’luk nötral formalin içerisinde fikse edilmiştir. Fiksasyon sonrası rutin histolojik doku takibine tabii tutulmuştur. Ardından parafin içine gömülerek bloklar elde edilip, $5 \mu$ mlik kesitler lamlar üzerine alınmıştır. Kesitlere, hücresel yapıları incelemek için Hematoksilen-Eozin (H-E), bazal membran yapısındaki değişiklikleri ve glikojen birikimini değerlendirmek için Periyodik Asit Schiff (PAS) ve kolajen matriksini göstermek için Masson Trikrom boyamaları yapılmıştır (12). Daha sonra ışık mikroskobu altında (Eclipse E-600, Nikon, Japan) görüntü analiz sistemi kullanılarak (NIS Elements Nikon, Japan) değerlendirilmiştir.

Glomerüler ve tübulointerstisyel hasar miktarının değerlendirilmesi semikantitatif bir yöntem kullanılarak yapılmıştır. Glomerüler yaralanma; mezengial matriks genişlemesi ve / veya hyalinozisle birlikte fokal adezyonlar, kapiller dilatasyon, glomerular oklüzyon ve sklerozisi içerecek şekilde değerlendirilmiştir. Tübulointerstisyel hasarın değerlendirmesinde tübüler dilatasyon, interstisyel fibroz ve tübüler hücre atrofisi parametreleri kullanılmıştır. Her bir böbrekte 40 glomerül, glomerüler hasarın şiddetine ve miktarına göre derecelendirilmiştir:

Grade 0, sağlam glomerulus;

Grade 1, glomerulusun \%25’ini içeren glomerüler hasar;

Grade 2, glomerulusun \%25 ile \%50'sini etkileyen glomerüler hasar;

Grade 3, glomerülün \%50 ile \%75’ini etkileyen glomerüler hasar; 
Grade 4, glomerulusun \%75'ini içeren ciddi hasar veya skleroz.

Kortekste bulunan tubulointerstisyal hasar için, tübüler ve interstisyel hasarın şiddetine ve miktarına göre yine 40 tubulointerstitial alan değerlendirildi;

Grade 0, tübüler yaralanma veya interstisyel fibrozis yok,

Grade 1, ilgili alanın \%25’inde,

Grade 2, ilgili alanın \%25 ile \%50’sinde,

Grade 3, ilgili alanın \%50 ile \%75’inde;

Grade 4, ilgili alanın \%75'inden fazla hasarlanmış tübül ve interstisyumu içerir (13).

\section{İmmünohistokimyasal Boyamalar}

Böbrek dokularından alınan kesitler, IL-6, FGF-1 ve p53 primer antikorlarıyla boyanarak değerlendirilmiştir. Deparafinize edilip rehidrate edilen kesitler sitrat buffer ( $\mathrm{pH}=6.0$ ) ile mikrodalgada $20 \mathrm{dk}$ antijen retrieval işlemine tabi tutulmuştur. Ardından endojen peroksidaz aktivitesini bloke etmek için \%3 hidrojen peroksit ile $12 \mathrm{dk}$ muamele edilmiştir. Arka plan boyanmasının önlenmesi için damlatılan solüsyonun ardindan IL-6 (P620, Thermo Scientific, 1/50 dilüsyon), FGF-1 (sc-7910, Santa- Cruz Biotechnology, 1/50), p53 (sc6243, Santa Cruz biotechnology, 1/50 dilüsyon) primer antikorlarıla bir gece $+4 \mathrm{C}^{\circ}$ de inkübe edilmiştir. Ertesi gün, HRP sekonder antikor kiti (Anti-polyvalent HRP, Labvision Corp, Fremont, CA) kullanılarak boyama tamamlanmıştır. Aminoetil karbazol (AEC) kullanılarak renklendirilmiş ve zıt boyama için Mayers hematoksilen kullanılmış ve su bazlı kapatıcı kullanılarak kapatılmıştır (12).

İnterlökin-6, FGF-1 ve p53 immünreaktivitelerinin değerlendirilmesinde, daha önce tanımlanmış olan histolojik skorlama metodu kullanılmıştır (14). Skorlama boyanmanın şiddeti ve miktarı baz alınarak hesaplanmıştır. Boyanan hücrelerin ortalama oranı semikantitatif olarak belirlenmiş ve skorlanmıştır.
Değerlendirilen hücrelerin sayısına göre;

Grade 0 , boyanma $<\% 1$,

Grade 1, \%1 ile \%25

Grade 2, \%26 ile \%50,

Grade 3, \% 51 ile \%75,

Grade 4 >\%75 olarak belirlenmiştir (14).

Boyanma şiddeti ise şu şekilde sınıflandırılmıştır; Grade 0, boyanma yok; Grade 1, zayıf boyanma; Grade 2, orta şiddette boyanma ve Grade 3, güçlü boyanma.

Her örnek için histolojik skor aşağıdaki gibi hesaplanmıştır (14).

H-skor = boyanma oranı $\times$ şiddet skoru

Tüm kesitler ışı mikroskobu altında değerlendirilmiştir (Eclipse E-600 Nikon, Japan) ve görüntü analiz sistemi (NIS Elements Nikon, Japan) ile incelenerek fotoğraflanmıştır.

\section{Verilerin İstatistiksel Değerlendirilmesi}

Elde edilen veriler Sosyal Bilimler için İstatistik Paket Programı 21.0 (Statistical Package for Social Science, version 21.0 SPSS-21.0) kullanılarak analiz edilmiştir. Gruplar arası farklılığın analizi için Kruskal Wallis testi, ikili karşılaştırmalar için ise Dunn testi kullanılmış, $\mathrm{p}<0.05$ değeri anlamlı olarak kabul edilmiştir.

\section{BULGULAR}

\section{Histokimya}

Böbreklerde hiçbir grupta, glomerüler atrofi, sklerozis, kapiller dilatasyon, glomerular oklüzyon veya interstisyel fibrosis, tübüler atrofi/dilatasyon gözlenmemiştir. Bununla beraber Grup 3'de (whey protein grubu) hafif mezengial matriks genişlemeleri olduğu görülmüştür (grade 1). Bunun dışında herhangi bir patolojiye rastlanmamıştır. Grup 1 (kontrol grubu) ve Grup 2'nin (sham grubu) normal morfolojiye sahip olduğu gözlenmiştir (Resim 1). 
Hematoksilen-Eozin

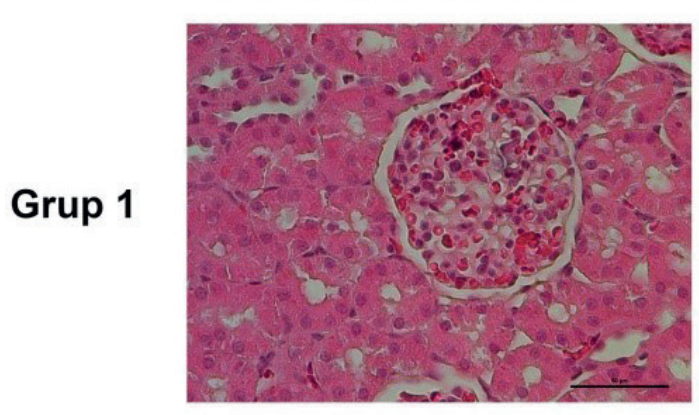

Grup 2

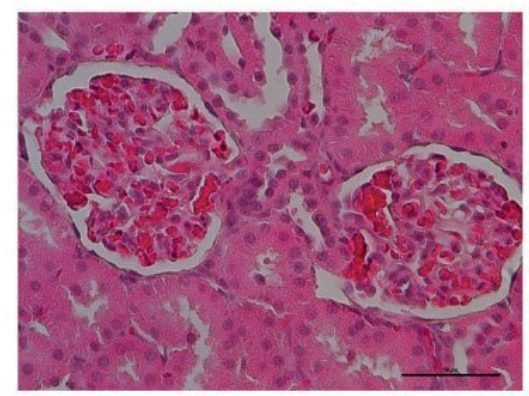

Grup 3

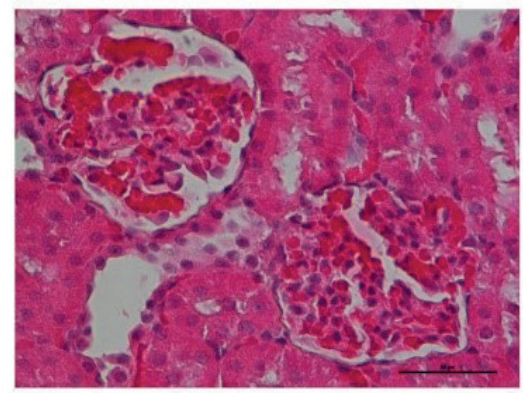

PAS
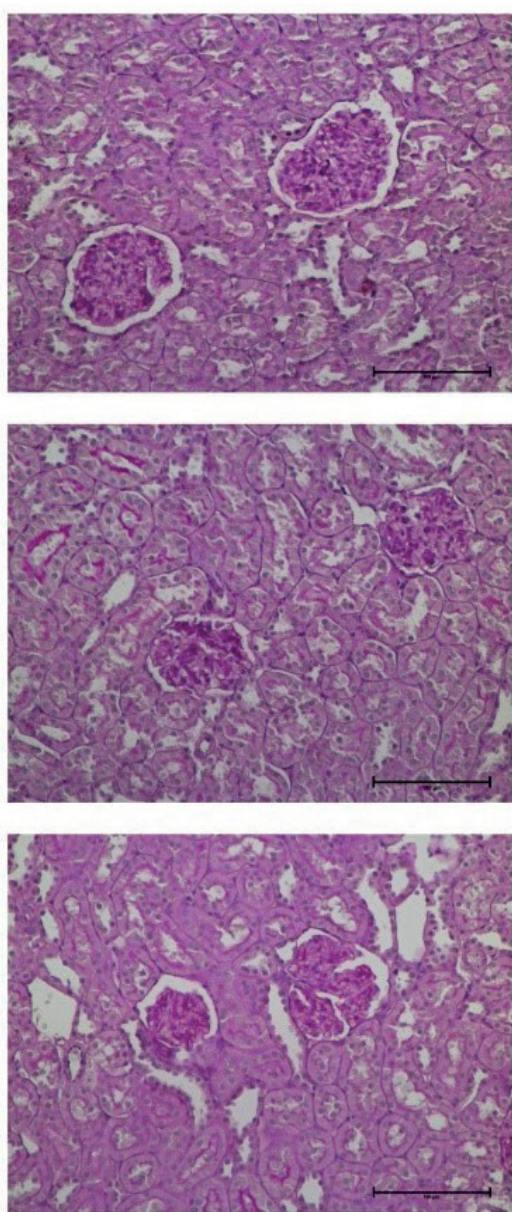

Masson Trikrom
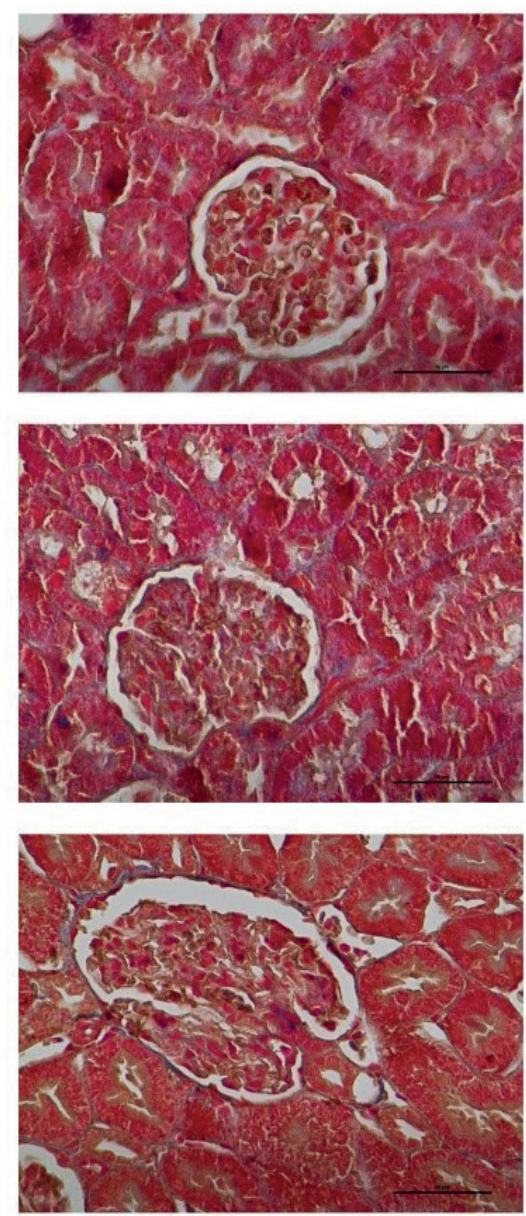

Resim 1. Böbrek dokularının hematoksilen-eozin, PAS, Masson trikrom boyalı resimleri PAS: Periyodik Asit Schiff

\section{İmmunohistokimyasal Bulgular}

Dokulara immunohistokimyasal olarak IL-6, FGF1 ve p53 antikorlarıyla boyamalar yapılmıştır (Resim 2). İnceleme sonrası istatistiksel olarak değerlendirilmiştir. Protein 53 boyanmalarında gruplar arasında anlamlı farklılık olmadığı gözlenmiştir ( $p>0.05)$. İnterlökin-6 boyanmalarının Grup 3'de (whey protein grubu) Grup 1 (kontrol grubu) ve Grup 2'ye (sham grubu) göre istatistiksel olarak anlamlı artış gösterdiği tespit edilmiştir $(p<0.05)$. Fibroblast Büyüme Faktörü-1 boyanmalarında ise sadece Grup 1 (kontrol grubu) ve Grup 3 (whey protein grubu) arasında istatistiksel olarak anlamlı fark $(\mathrm{p}<0.05)$, Grup 3'deki (whey protein grubu) boyanmanın diğer iki gruptan fazla olduğu gözlenmiştir (Tablo1).

\section{TARTIŞMA}

Whey protein, sporcular için diyet takviyesi olması nedeni ile besin endüstrisinde yaygın olarak kullanılmaktadır (15,16). Birçok çalışma, whey proteinin egzersiz performansını ve kas protein sentezini artırma, redoks dengesini ve kardiyovasküler sağlığı iyileştirme yönündeki

Tablo 1. Gruplar arası IL-6 ve FGF-1 immunohistokimyasal boyanma skorlarının istatistiksel karşılaştırması

\begin{tabular}{lcc}
\hline & $\begin{array}{c}\text { IL-6 } \\
\text { p değeri }\end{array}$ & $\begin{array}{c}\text { FGF-1 } \\
\text { p değeri }\end{array}$ \\
\hline Grup 1 - Grup 2 & 0.887 & 0.052 \\
Grup 1 - Grup 3 & 0.003 & 0.015 \\
Grup 2 - Grup 3 & 0.005 & 0.627 \\
\hline
\end{tabular}

IL-6: İnterlökin-6, FGF-1: Fibroblast Büyüme Faktörü-1 


\section{FGF-1}

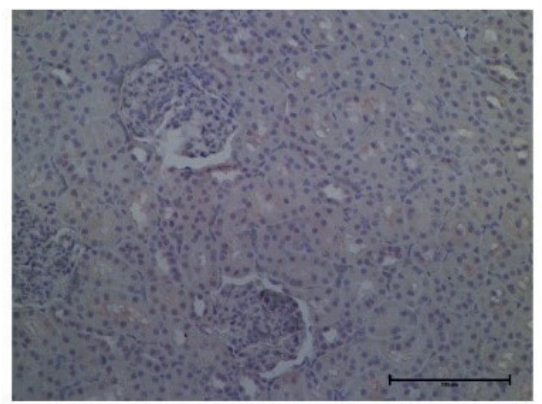

Grup 1

Grup 2

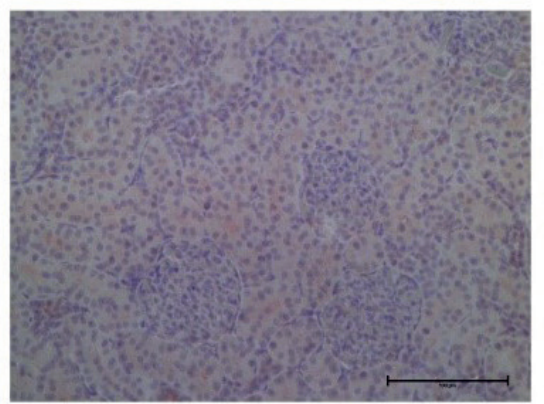

Grup 3

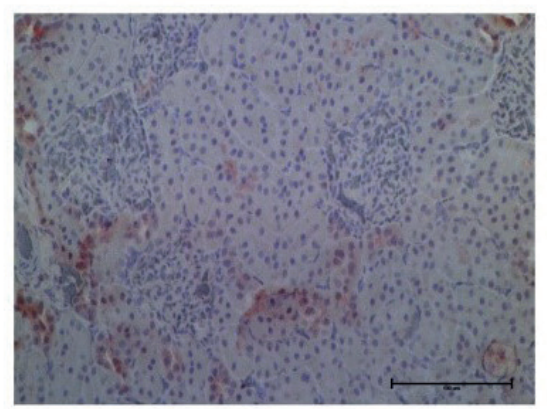

p 53
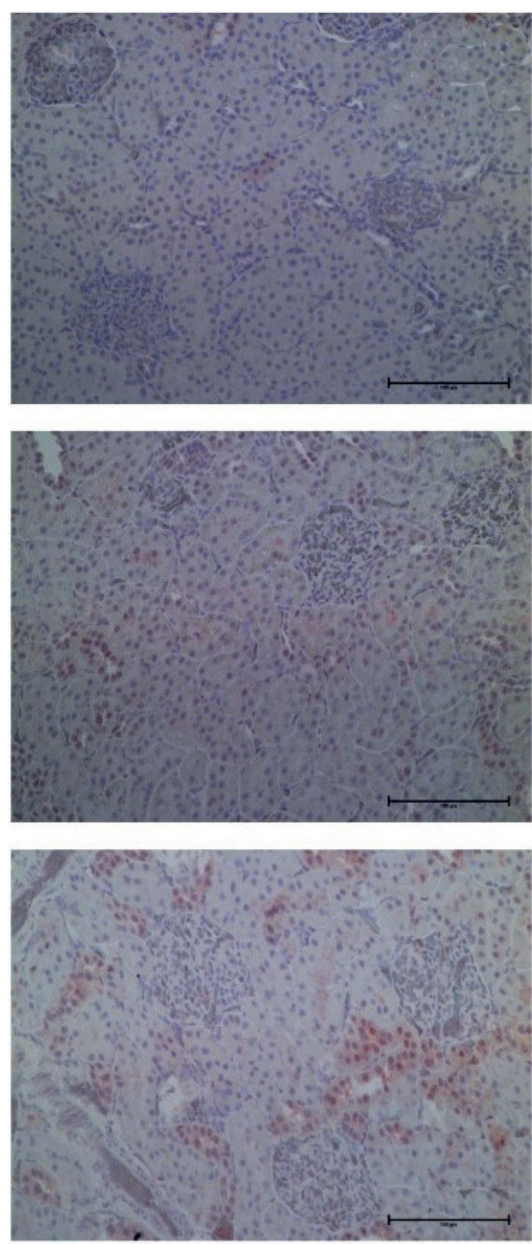

IL-6
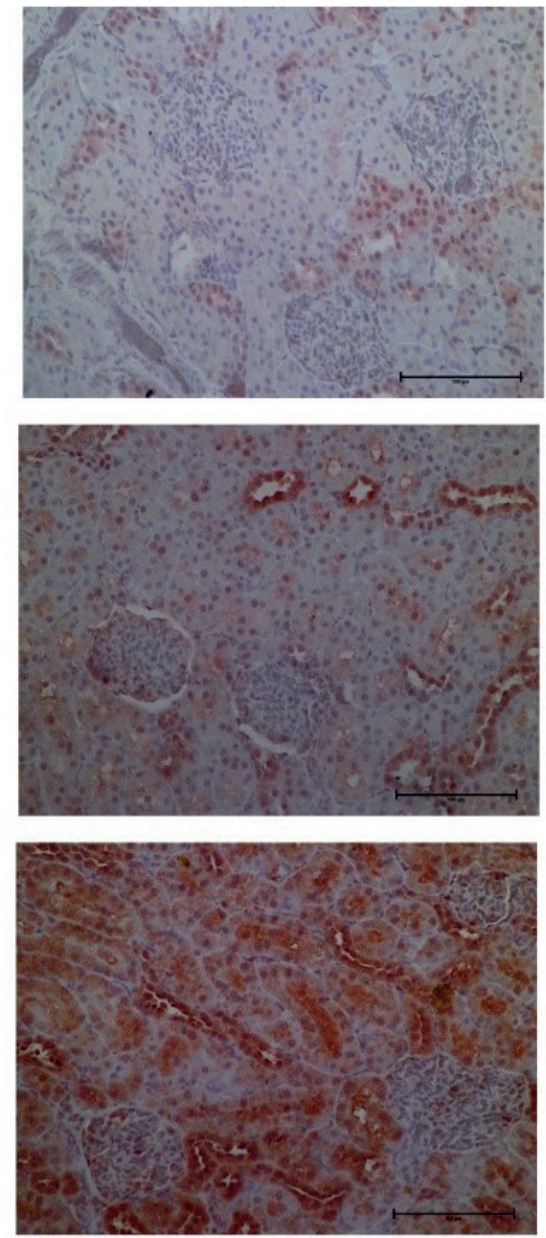

Resim 2. İmmunohistokimyasal olarak boyanmış böbrek dokularının fotoğrafları FGF-1: Fibroblast Büyüme Faktörü-1, p 53: protein 53, IL-6: İnterlökin-6

faydalarını bildirmiştir (17,18). Bununla birlikte whey proteininin metabolizma ve bağı̧̧ıllık sistemi, yara iyileşmesi, öğrenme ve yaşlanma karşıtı pozitif etkilerinin olduğu belirtilmiştir $(19,20)$.

Böbrekler, tüm vücudun homeostazisini korumaya yardımcı olan bir dizi düzenleyici önemli işlevlerde yer alır. İnterlökin-6 sitokin ailesinin üyelerinden birisi olup, hem pro-inflamatuvar, hem de antiinflamatuvar etkilere sahip çok işlevli bir sitokindir. İnterlökin-6 hem akut hem de kronik böbrek hastalığında önemli rol oynamaktadır. Diyabetik nefropati, glomerülonefrit ve obstrüktif nefropati gibi böbrek hastalıklarında böbrek dokusunda IL-6 düzeyleri artmış olarak bulunmuştur. İnterlökin-6’yı eksprese eden ve salgılayan böbrek hücreleri arasında podositler, endotel hücreleri, mezengial hücreler ve tübüler epitel hücreleri bulunmaktadır. İnterlökin-6 bu tür hücrelerde hücre proliferasyonunu, tübülointerstisyel fibrozisi arttırır veya farklılaşmayı etkiler (21). Literatürde yer alan bilgiler ışı̆ında; bu çalışmada, bir ay boyunca oral gavajla whey proteini verilmiş olan sıçanların böbrek dokularında IL-6 katılımı ile renal patolojiye katılma olasılığı görülmek istenilmiştir. İnterlökin-6 boyanmalarının Grup 3'de (whey protein grubu) Grup 1 (kontrol grubu) ve Grup 2'ye (sham grubu) kıyasla istatistiksel olarak anlamlı artış gösterdiği saptanmıştır ( $\mathrm{p}<0.05)($ Resim 2$)$ (Tablo 1). Bununla birlikte çalışma gruplarında glomerüler atrofi, sklerozis, kapiller dilatasyon, glomerular oklüzyon veya interstisyel fibrozis, tübüler atrofi/ dilatasyon gözlenmemiş̧ir. Ancak whey grubundaki 
böbrek dokularında grade 1 düzeyde hafif mezengial matriks genişlemeleri olduğu görülmüştür (Resim 1).

İnterlökin-6’nın çeşitli böbrek hastalıklarının patolojisine katılmasindan dolayl, IL-6 düzeyleri ve aktivitesi hastalık şiddeti ve ilerlemesi için ön belirteç olarak kullanılabilir (22). Böbrek hastalıklarında değerlendirilen belirteçler karmaşıktır, örneğin bazen faydalı görünürlerken bazen patojenik görünebilirler. Böbrek hastalıklarının sıklıkla diyabet veya hipertansiyon gibi diğer hastalıklarla ortaya çıkması, hastalığın prognozunu daha da karmaşıklaştırır. Sitokinler ve böbrek hastalıkları arasındaki bu karmaşık etkileşimi çözmek için in vitro hayvan modellerinde daha fazla çalışma gerekmektedir (23).

Progresif böbrek hastalığı glomerüloskleroz, tubulointerstisyel fibrozis ve vasküler sklerozis ile karakterizedir. Çok sayıda faktör, örneğin büyüme faktörleri, kemokinler, sitokinler ve reaktif oksijen örnekleri ilerleyici böbrek skarlaşmasında bu sürece dahil edilir (24,25). Normal böbreklerde, FGF-1 tübüler epitel hücrelerinde eksprese edilmez. Buna karşılık, FGFR-1 normalde tübüler epitelde ve ayrıca arteriyel endotelde ve düz kasta lokalize edilmiştir. Böbreklerde inflamasyon durumlarinda FGF-1 tübüler epitel hücrelerde hafifçe artarken, tübüllerde negatif kaldığı gösterilmiştir (26). Fibroblast Büyüme Faktörü-1'in böbrek hastalıklarındaki rolü çok az bilinmekle birlikte, yetişkin dokularında yaralanma bölgelerinde yara iyileşme sürecinin farklı aşamalarında rol oynadığı öne sürülmektedir (27). Böbrek hastalığında FGF-1 rolünün potansiyel rolü başta transplantasyonlar olmak üzere sadece birkaç çalışmada araştırılmıştır (28-31). Bu büyüme faktörünün ayrıca diğer inflamasyon koşullarında da rol oynayabileceği bilinmektedir. Önceki çalışmalarda transplantasyon yapılan böbreklerde FGFR-1 ekspresyonunda kan damarlarında ve tubulointerstisyel kompartımanında kontrollere kıyasla özellikle proliferasyon ve inflamasyon alanında artış bulunmuştur $(28,29)$. Benzer başka bir çalışmada, glomerüllerde sadece viseral ve paryetal epitel hücrelerinde FGF-1 artışı gözlenmiştir (30). Diğer bir çalışmada, interstisyumda inflamatuvar hücre infiltratları ve buna karşılık gelen FGF-1 ekspresyonu temel olarak fibrozis alanında ilişkili bulunmuştur. Ek olarak, normal kontrollerle karşılaştırıldığında, FGFR-1 ekspresyonu hastalıklı tübüllerde hafifçe artmıştır (31). Bu sonuçlar infiltrasyon hücrelerinde FGF-1'in tubulointerstisyel mitojenik özellikleri sayesinde yaralanma sonrası yeniden modellemede rol oynayabileceğini önermektedir (32).

Bu çalışmada, 30 gün süresince oral gavaj ile whey proteini verilen sıçan modelinde whey proteinin sitokin ailesinden birisi olan IL-6 ve bir büyüme faktörü olan FGF-1 üzerinden böbrek dokusu üzerinde yapabileceği olası histopatolojik değişiklikler incelenmiştir.

Bu çalışmanın en güç ve en önemli aşaması kullanılan tekniktir. Sıçanlara bir ay boyunca her gün oral gavaj yapılmasının tahriş edici etkisinden dolayı besin alımında bir miktar azalma meydana gelebileceği ön görülerek, sıçanların belirli periyotlarda ağırlık takibi yapılmış ve \%15’den fazla vücut ağırlık kaybı olan sıçanlar çalışma dışında bırakılmıştır. Oral gavaj uygulama sırasında sıçanların boyun derisinden yakalama tekniği kullanılarak, uygulanan solüsyonun sıçanın trakeasına kaçmaması ve özofagusunun yaralanmaması için özen gösterilerek oluşabilecek travmaların önüne geçilmeye çalışılmıştır.

Çalışmadan elde edilen sonuçlara göre antioksidan ve anti-inflamatuvar etkileri olan whey proteininin, whey proteini verilen grupta siçanların böbrek dokularında hafif mezengial matriks genişlemeler oluşturduğu halde bunun dışında herhangi bir histolojik değişiklik yapmadığı belirlenmiştir. Whey proteini verilen gruplarda IL-6 ve FGF-1 ekspresyonlarının artmış düzeyleri istatistiksel olarak anlamlı değişiklik göstermiş olması, whey proteinin fizyopatolojik deneysel hayvan modellemelerinde işe karışabileceğini göstermesi açısından önemlidir.

Çıkar çatışması - Conflict of interest: Yazarlar çıkar çatışması olmadığını beyan ederler. - The authors declare that they have no conflict of interest. 


\section{KAYNAKLAR}

1. Akkurt G. The effect of isolated hydrolyzed whey protein on thyroid hormones, liver and kidney function tests in individuals with regular weight exercise. Ankara Med J. 2019;(1):178-86.

2. Tsutsumi R, Tsutsumi YM. Peptides and proteins in whey and their benefits for human health. Austin J Nutri Food Sci. 2014;1:1002.

3. Kayapinar O, Ozde C, Koc Ay E, Keskin M, Kaya A. Anterior myocardial infarction in a 26-year-old body builder with concomitant use of whey protein powder and amino acid capsules. Acta Cardiol Sin. 2018;34:35962.

4. Wirunsawanya K, Upala S, Jaruvongvanich V, Sanguankeo A. Whey protein supplementation improves body composition and cardiovascular risk factors in overweight and obese patients: A systematic review and meta-analysis. J Am Coll Nutr. 2018;37:60-70.

5. El-Shinnawy NA, Abd Elhalem SS, Haggag NZ, Badr G. Ameliorative role of camel whey protein and rosuvastatin on induced dyslipidemia in mice. Food Funct. 2018;21:1038-47.

6. Pal S, Radavelli BS. The effects of whey protein on cardiometabolic risk factors. Obes Rev. 2013;14:324-43.

7. Bjørnshave A, Holst JJ, Hermansen K. A pre-meal of whey proteins induces differential effects on glucose and lipid metabolism in subjects with the metabolic syndrome: A randomised cross-over trial. Eur J Nutr. 2019;58:755-64.

8. Beaulieu J, Dupont C, Lemieux P. Anti-inflammatory potential of a malleable matrix composed of fermented whey proteins and lactic acid bacteria in an atopic dermatitis model. J Inflamm. 2007;4:6-15.

9. Bounous G, Kongshavn PA. Differential effect of dietary protein type on the B-cell and T-cell immune responses in mice. J Nutr. 1985;115:1403-8.

10. Bland JS. CNS: Functional medicine pioneer. Altern Ther Health Med. 2004;10(5):74-81.

11. Nunes A, Silva P, Alves J, Stefani G, Petry M, Rhoden C, et al. Effects of resistance training associated with whey protein supplementation on liver and kidney biomarkers in rats. Appl Physiol Nutr Metab. 2013;38:1166-9.

12. Bradbury P, Gordon KC, Cook HC. Theory and Practice of Histological Techniques, edited by Bancroft Jd, Stevens A, London: Churchill Livingstone; 1982.122 p.

13. Cao Z, Bonnet F, Candido R, Nesteroff SP, Burns WC, Kawachi $\mathrm{H}$, et al. Angiotensin type 2 receptor antagonism confers renal protection in a rat model of progressive renal injury. J Am Soc Nephrol. 2002;13(7):1773-87.

14. Wang $\mathrm{H}$, Chen P, Liu XX, Zhao W, Shi L, Gu XW, et al. Prognostic impact of gastrointestinal bleeding and expression of PTEN and Ki-67 on primary gastrointestinal stromal tumors. World J Surg Oncol. 2014;12:89.

15. Schmitt C, Bovay C, Rouvet M, Shojaei RS, Kolodziejczyk E. Whey protein soluble aggregates from heating with NaCl: Physicochemical, interfacial and foaming properties. Langmuir. 2007;23(8):4155-66.

16. Zhong Q, Jin M. Enhanced functionalities of whey proteins treated with supercritical carbon dioxide. J Dairy Sci. 2008;91:490-99.

17. Tang JE, Moore DR, Kujbida GW, Tarnopolsky MA, Phillips SM. Ingestion of whey hydrolysate, casein or soy protein isolate: Effects on mixed muscle protein synthesis at rest and following resistance exercise in young men. J Appl Physiol. 2009;107:987-92.

18. Singh A, Zapata RC, Pezeshki A, Knight CG, Tuor UI, Chelikani PK. Whey protein and its components lactalbumin and lactoferrin affect energy balance and protect against stroke onset and renal damage in saltloaded, high-fat fed male spontaneously hypertensive stroke-prone rats. J Nutr. 2020;150(4):763-74.

19. Haraguchi FK, Pedrosa ML, de Paula H, dos Santos RC, Silva ME. Evaluation of biological and biochemical quality of whey protein. J Med Food. 2010;13:1505-09.

20. Krissansen GW. Emerging health properties of whey proteins and their clinical implications. J Am Coll Nutr. 2007;26:713-23.

21. Su H, Lei CT, Zhang C. Interleukin-6 signaling pathway and its role in kidney disease: An update. Front Immunol. 2017;8: 405.

22. Jones SA, Fraser DJ, Fielding CA, Jones GW. Interleukin-6 in renal disease and therapy. Nephrol Dial Transplant. 2015;30: 564-74.

23. Magno AL, Herat LY, Carnagarin R, Schlaich MP, Matthews VB. Current knowledge of IL-6 cytokine family members in acute and chronic kidney disease. Biomedicines. 2019;7(1):19.

24. Iwano M, Plieth D, Danoff TM, Xue C, Okada H, Neilson EG. Evidence that fibroblasts derive from epithelium during tissue fibrosis. J Clin Invest. 2002;110:341-50.

25. Kalluri R, Neilson EG. Epithelial-mesenchymal transition and its implications for fibrosis. J Clin Invest. 2003;112:1776-84.

26. Rossini M, Cheunsuchon B, Donnert E, Ma LJ, Thomas JW, Neilson EG, et. al. Immunolocalization of fibroblast growth factor-1 (FGF-1), its receptor (FGFR-1), and fibroblast-specific protein-1 (FSP-1) in inflammatory renal disease. Kidney Int. 2005;68(6):2621-8.

27. Powers CJ, Mcleskey SW, Wellstein A. Fibroblast growth factors, their receptors and signaling. Endocr Relat Cancer. 2000;7:165-97. 
28. Kerby JD, Luo KL, Ding Q, TagouriY, Herrera GA, Diethelm $\mathrm{AG}$, et al. Immunolocalization of acidic fibroblast growth factor and receptors in the tubulointerstitial compartment of chronically rejected human renal allograft. Transplantation. 1997;63:988-95.

29. Kerby JD, Verran DJ, Luo KL, Ding Q, Tagouri Y, Herrera GA, et al. Immunolocalization of FGF-1 and receptors in human renal allograft vasculopathy associated with chronic rejection. Transplantation. 1996;62:467-75.

30. Kerby JD, Verran DJ, Luo KL, Ding Q, Tagouri Y, Herrera $\mathrm{GA}$, et al. Immunolocalization of FGF-1 and receptors in glomerular lesions associated with chronic human renal allograft rejection. Transplantation. 1996;62:190200.

31. Zinn KR, Kelpke S, Akhi K, Viera L, Chaudhuri TR, Thompson JA. Glomerular targeting of acidic fibroblast growth factor-1 in renal transplanted rats. Transplantation. 2002;73:1447-54.

32. Anderson RJ, Ray CJ. Potential autocrine and paracrine mechanisms of recovery from mechanical injury of renal tubular epithelial cells. Am J Physiol. 1998;274:46372 . 